\title{
Lip Squamous Cell Carcinoma
}

National Cancer Institute

\section{Source}

National Cancer Institute. Lip Squamous Cell Carcinoma. NCI Thesaurus. Code C4042.

A squamous cell carcinoma that arises from the lip. It affects males more often than females and it usually involves the lower lip. Risk factors include UV exposure, alcohol consumption, smoking, and immunosuppression. 